Arq. Bras. Med. Vet. Zootec., v.69, n.6, p.1565-1572, 2017

\title{
Nitric oxide and immune response in infection control of Caseous Lymphadenitis
}

\author{
[Óxido nítrico e resposta imune no controle de infecção da Linfadenite Caseosa] \\ M.G. Oliveira Neto ${ }^{1}$, H.A. Santos ${ }^{1}$, R.E. Fraga ${ }^{1}$, A.S. Pacheco ${ }^{1}$, G.P. Sampaio ${ }^{1}$, L.F. Moura-Costa ${ }^{1}$, \\ R. Meyer ${ }^{1}$, M. Costa Silva ${ }^{1}$, S.C. Trindade ${ }^{2}$, V.L.C. Vale $^{3}$ \\ ${ }^{1}$ Universidade Federal da Bahia - Salvador, BA \\ ${ }^{2}$ Universidade Estadual de Feira de Santana - Feira de Santana, BA \\ ${ }^{3}$ Universidade do Estado da Bahia - Alagoinhas, BA
}

\begin{abstract}
This study aimed to evaluate aspects of host immune response using an experimental infection model of Corynebacterium pseudotuberculosis (CP) in C57/Black6 wild-type and knockout for nitric oxide (KONO) mice. 28 mice were evaluated: 4 wild-type controls; 10 wild-type infected with CP; 4 KO-NO controls; $10 \mathrm{KO}-\mathrm{NO}$ infected with $\mathrm{CP}$. Infection procedures were carried out by intraperitoneal inoculation using $10^{7}$. Infected C57/Black6 KO-NO mice began to die after the $5^{\circ}$ day post-inoculation, up until the $14^{\circ}$ day. Neutrophils were found in increased numbers in the infiltrate of KO-NO murine peritoneal cavities. Examination of splenic tissue revealed an accumulation of lymphocytes, predominantly CD8 T-cells, in experimental animal groups. KO-NO animals were found to have a predominance of granulomas 7 days post-inoculation, primarily in the lymph nodes. In addition, greater amounts of bacteria were recovered from the mesenteric lymph nodes of KO-NO mice. There was no statistically significant difference in the levels of total $\operatorname{IgG}$ and its subclasses 14 days post-inoculation between KO-NO and wild groups. The results suggest the importance of nitric oxide in the process of controlling $\mathrm{CP}$ infection, as KO-NO animals were observed to be markedly more affected by infection with this bacterium.
\end{abstract}

Keywords: nitric oxid, knockout mice, Corynebacterium pseudotuberculosis, caseous limphadenitis

\section{RESUMO}

O objetivo deste estudo foi avaliar os aspectos da resposta imune do hospedeiro, mediante o uso de um modelo experimental de infecção de Corynebacterium pseudotuberculosis (CP) em camundongos C57/Black6 do tipo selvagem e em C57/Black6 knockout para o óxido nítrico (KO-NO). Foram avaliados 28 camundongos: quatro controles de tipo selvagem; 10 do tipo selvagem infectados com CP; quatro controles KO-NO; e $10 \mathrm{KO}-\mathrm{NO}$ infectados com CP. A infecção foi realizada via intraperitoneal, usandose $10^{7}$. Os animais C57/Black6 KO-NO infectados começaram a vir a óbito no quinto dia pós-inoculação, o que aconteceu até o $14^{\circ}$ dia. Um número maior de neutrófilos foi encontrado na sua cavidade peritoneal. $O$ exame do baço revelou um acúmulo de linfócitos, predominantemente células $T C D 8$, nos grupos de animais experimentais. Nos animais KO-NO, foi observada a presença de granulomas, sete dias pós-inoculação, principalmente nos gânglios linfáticos. Além disso, uma maior quantidade de bactérias foi detectada dos linfonodos mesentéricos desses animais. Não houve diferença estatisticamente significante nos níveis séricos IgG total e em suas subclasses aos 14 dias pós-inoculação nos grupos KONO e selvagem. Os resultados obtidos sugerem a importância do óxido nítrico no processo de controle da infecção por CP.

Palavras-chave: óxido nítrico, camundongos Knockout, Corynebacterium pseudotuberculosis, linfadenite caseosa

Recebido em 17 de março de 2016

Aceito em 23 de fevereiro de 2017

E-mail: milbio79@yahoo.com.br 


\section{INTRODUCTION}

Sheep and goat livestock production is a crucially important economic activity in many regions around the world, especially in northeastern Brazil. A major challenge faced by individuals whose livelihood depends on raising small ruminants is the etiological agent of Caseous Lymphadenitis (CL), a disease which is known to target these animals. CL causes considerable economic losses due to reductions in reproductive efficiency and the production of wool, meat and milk, with damage to animals' skins and carcasses resulting from the presence of abscesses (Guimarães et al., 2009). The treatment of the disease also incurs elevated financial cost. The bacterium Corynebacterium pseudotuberculosis, a gram-positive facultative intracellular bacillus in macrophages (Ramos et al., 2012), is responsible for CL, entering animals' bodies via the skin or mucosa (Motta et al., 2010). The spread of this bacterium results in the formation of granulomatous lesions that can affect not only the superficial regions (superficial lymphatic ganglia), but also internal organs, including the lungs, spleen, kidneys and liver (Oliveira et al., 2011).

The role of innate immunity against $\mathrm{CP}$ is crucially important to understand the pathogenesis of CL. The participation of neutrophils, mononuclear phagocytes and NK "natural killer" cells (Dias et al., 2011) is fundamental for phagocytosis, a process resulting in the destruction of microorganisms. However, due to the resistance of this intracellular bacteria to degradation within phagocytes, there are significant challenges to infection control and eradication efforts (Bastos et al., 2012).

Taking into account the fact that nitric oxide (NO) constitutes one of the most important innate defense molecules involved in the eradication of infectious agents (Trost et al., 2010), the present study sought to investigate, in vivo, the role played by $\mathrm{NO}$ in the immune response to $\mathrm{CP}$ within the context of an experimental murine infection model.

KO-NO mice were chosen in an attempt to gain insight into how some immune system cell types act against this pathogen, since it is known that NO plays an important role in the elimination of intracellular microorganisms.
The present study aimed to evaluate aspects of host immune response using an experimental infection model of $\mathrm{CP}$ in C57/Black6 wild-type and $\mathrm{KO}-\mathrm{NO}$ mice.

\section{MATERIAL AND METHODS}

The protocol for this experiment was reviewed and approved by the Ethics Committee on Animal Use (CEUA), Federal University of Bahia under number 006/2010.

A total of 28 female mice aged 6-8 weeks were initially divided into two groups: 14 C57/Black6 KO-NO and 14 wild-type C57/Black6 mice, acquired from the Animal Care Facility of the Oswaldo Cruz Institute, RJ (FIOCRUZ-RJ). These animals were further subdivided to obtain two uninfected control groups (4 wild-type and 4 KO-NO), while the remaining mice $(n=20)$ were infected with an attenuated strain of $C$. pseudotuberculosis. Animals were euthanized at 7 days post-inoculation (7dpi) and 14 days postinoculation (14dpi) (two from each control group and five from each experimental group at each time point).

For infection purposes, an attenuated strain of Corynebacterium pseudotuberculosis, denominated T1, was obtained from the collection of the Laboratory of Microbiology at the Health Sciences Institute (ICS-UFBA). This particular strain was originally identified by the same laboratory using the "API coryne" test (BioMérieux AS, Marcy-l'Etoile, France).

Thus, the study was composed of four groups: uninfected C57/Black6 knocked out mice (KONO control), C57/Black6 knocked out mice infected with T1 strain (KO-NO T1), uninfected C57/Black6 wild-type mice (WT control) and C57/Black6 wild-type mice infected with T1 strain (WT T1).

The bacterial inoculate used in the present study was grown in brain-heart infusion (BHI) medium at $37^{\circ} \mathrm{C}$ for 48 hours. Infection procedures were carried out by intraperitoneal inoculation, using $10^{7}$ colony forming units (CFU) of the T1 strain of $\mathrm{CP}$ diluted in $1 \mathrm{ml}$ of saline solution (PBS $0.15 \mathrm{M}, \mathrm{pH} 7.4$ ). All control mice received $1 \mathrm{ml}$ of saline solution (PBS 0.15M, $\mathrm{pH} 7.4$ ) through the same inoculation route. 
Blood was obtained by cardiac puncture to acquire murine serum. The antigen secreted by CP (Carminati et al., 2003) was used to quantitate specific IgG and its subclasses by indirect ELISA in infected mice.

Murine peritoneum were washed with saline solution and leukocytes were recovered by aspiration. A total count of these cells was subsequently made using an automatic counter (CELM, model DC-530, Alphaville-Barueri-São Paulo, Brasil) and whole blood cells (WBC) differential counts were performed by smear slide preparation. The mesenteric lymph node was also inspected to quantify bacterial CFU by incubating $100 \mathrm{ml}$ of saline rich in lymph node cells in a petri dish with BHI agar for 48 hours at $37^{\circ} \mathrm{C}$.

After this procedure, all animals were weighed on a precision scale, and then, the spleens were carefully removed and weighed too. To evaluate the immune markers CD3, CD4 and CD8, a cellular suspension was obtained using a $5 \mathrm{~mL}$ syringe plunger to macerate $40 \mathrm{mg}$ of splenic tissue together with $1 \mathrm{~mL}$ of protease inhibitor solution (Protease Inhibitor Cocktail - Sigma Aldrich). Cells were then stained with anti-CD3, CD4 and CD8 antibodies (Invitrogen, Carlsbad, CA, USA) and readings were taken using a flow cytometer (FACS calibur- produced by BD, Becton Dickinson, San Jose, USA).

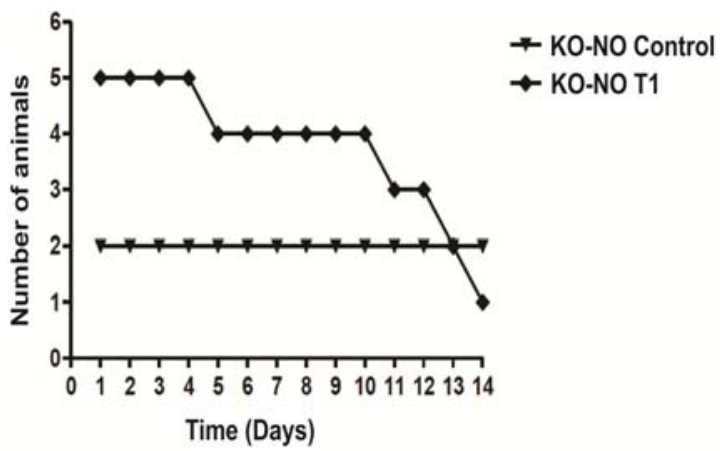

Figure 1. Mortality curve for C57/Black6 KO-NO mice 14dpi with $10^{7} \mathrm{CFU}$ of $\mathrm{CP}$.

The present study found a high rate of mortality among the KO-NO mice with impaired NO synthesis, confirming the role of this substance as one of the main cytotoxic mediators in activated immune effector cells (Ozbek et al.,
The nonparametric Kruskal-Wallis test was used to detect possible differences among groups. Pair-wise comparisons were analyzed using the Mann-Whitney nonparametric test with Bonferroni correction. Statistical Package for Social Sciences $\left(\right.$ SPSS $\left.^{\circledR}\right)$ software version 17.0 was used for data analysis and Graph Pad Prism $5^{\circledR}$ software was used to construct all graphs.

\section{RESULTS AND DISCUSSION}

The mortality curve shows that the C57/Black6 $\mathrm{KO}-\mathrm{NO}$ mice began to decease on the $5^{\circ}$ day pos-inoculation (Figure 1). Interestingly, similar outcomes were not observed in the wild-type mice (data not shown). This result highlights the importance of NO with respect to these animals innate immune response. However, from the proteomic screening of $\mathrm{CP}$ in the presence of NO, Silva et al. (2014) identified a set of factors that influence CP resistance and survival during a nitrosative exposure period. At $7 \mathrm{dpi}$ both the infected wild-type and the KO-NO mice presented statistically significant differences with respect to carcass weight and spleen weight $(\mathrm{P}=0.009)$. Nonetheless, this difference did not persist after 14dpi, although absolute weight values remained higher in the $\mathrm{KO}-\mathrm{NO}$ mice Figure 2.

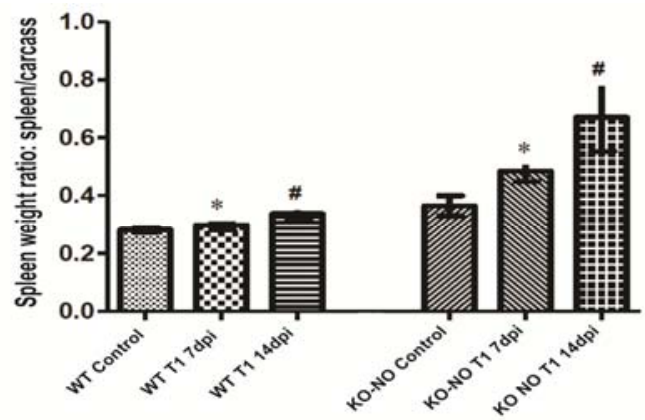

Figure 2. Relative spleen weight of C57/Black6 wild-type and KO-NO mice infected with $10^{7} \mathrm{CFU}$ of $\mathrm{CP}(\mathrm{P}=0.009)$.

2009). As KO-NO animals are unable to produce the iNOS enzyme, which is responsible for NO production, the IFN- $\gamma$ produced in response to bacterial stimuli is incapable of potentiating the microbicidal function of macrophages through 
the synthesis of reactive oxygen intermediates and NO (Charo and Ransohoff, 2006), thereby resulting in increased susceptibility to infection (Borges et al. 2009).
At $7 \mathrm{dpi}$, the average number of cells in the peritoneal cavities of infected KO-NO mice was significantly higher $(\mathrm{P}=0.009)$ than in the wildtype animals. Nevertheless, at 14dpi, no significant differences were observed between the two experimental groups (Figure 3).

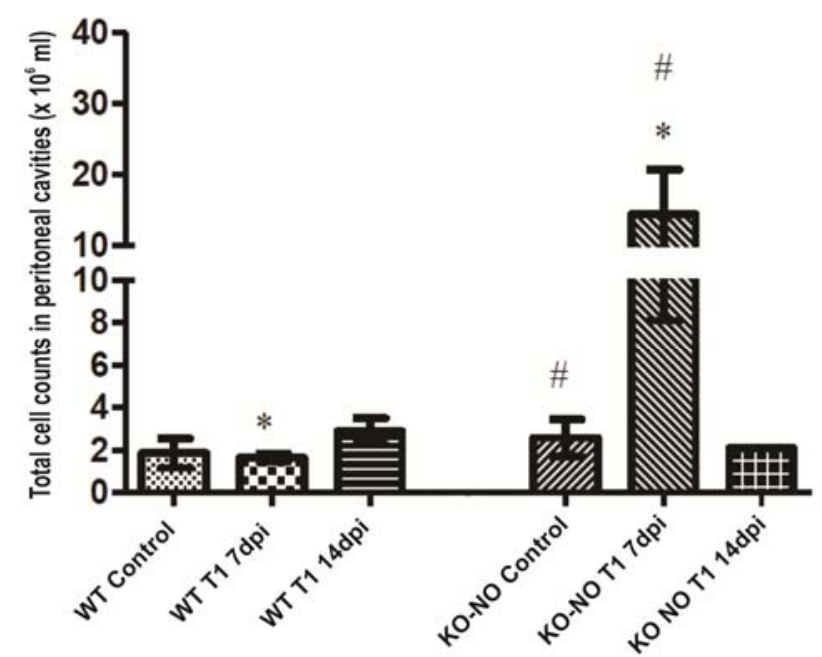

Figure 3. Total number of cells in aspirate from control and infected C57/Black6 wild-type and KO-NO mice. At 7dpi, the average number of cells in the peritoneal cavities of infected $\mathrm{KO}-\mathrm{NO}$ mice was significantly higher $(\mathrm{P}=0.009)$ than in the wild-type animals. Nevertheless, at $14 \mathrm{dpi}$, no significant differences were observed between the two experimental groups

Total macrophage counts were higher when comparing the infected $\mathrm{KO}-\mathrm{NO}$ mice to their wild-type counterparts, but this difference was seen only at $7 \mathrm{dpi}(\mathrm{P}=0.021)$ and was not maintained until the final time point evaluated (14dpi) (Figure 4A). Regarding neutrophil counts, the KO-NO mice presented higher quantities compared to the wild-type animals at $7 \mathrm{dpi}$. This increase was also observed at 14dpi, yet without statistical significance $(\mathrm{P}=0.051)$ despite further increases in count disparity (Figure 4B). With respect to mast cell counts, no significant differences were observed between the study groups evaluated (Figure 4C). KO-NO animals also presented a significant increase in the number of lymphocytes at 7dpi when compared to wild-type mice $(\mathrm{P}=0.016)$, while at 14dpi a non-statistically significant increase in the number of lymphocytes was observed in the KO-NO group $(\mathrm{P}=0.051)$ (Figure 4D).

Greater numbers of cells at the site of infection is a mechanism that is crucial to the elimination of invading pathogens. This occurs mainly by way of phagocytosis, carried out by macrophages and neutrophils, the first line of defense, and thusly associated with innate host immune response. In addition, these cells are responsible for the production and release of $\mathrm{NO}$ and reactive oxygen intermediates (ROIs) in the microenvironment, resulting in improved cytotoxicity (Dusse et al., 2003).

The data reported herein indicate that infected wild-type C57/Black6 mice presented a consistent number of leukocytes in the peritoneal cavity. No differences were observed among the time points analyzed, suggesting that the cells involved in immune response, naturally present in this region, such as macrophages, lymphocytes and B-1 mast cells, do not require an increased amount of blood cells to resolve or contain the onset of infection. On the other hand, the evaluation of the infected KO-NO mice indicated a greater need of cellular support to contain the infection, likely related to the absence of NO production, which hindered the action of phagocytic cells, facilitating bacterial survival, growth and dissemination, and thus necessitating additional blood cells. It was observed an 
increased number of neutrophils in the peritoneal cavities of KO-NO mice. Possibly, the lack of NO production forced the neutrophil migration as a compensatory mechanism. Accordingly,

A

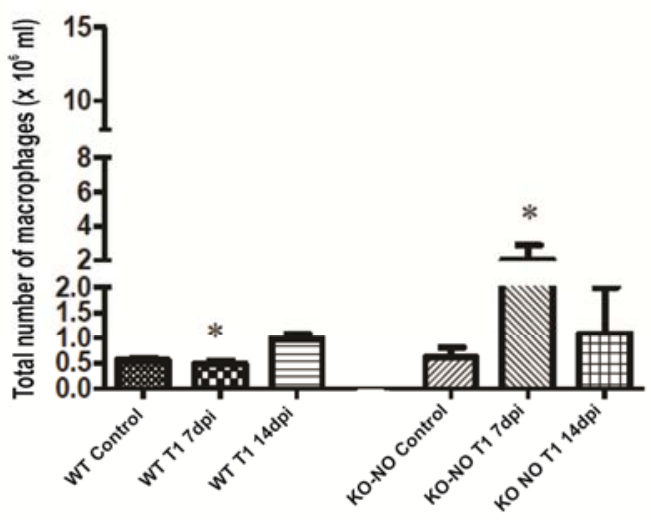

C

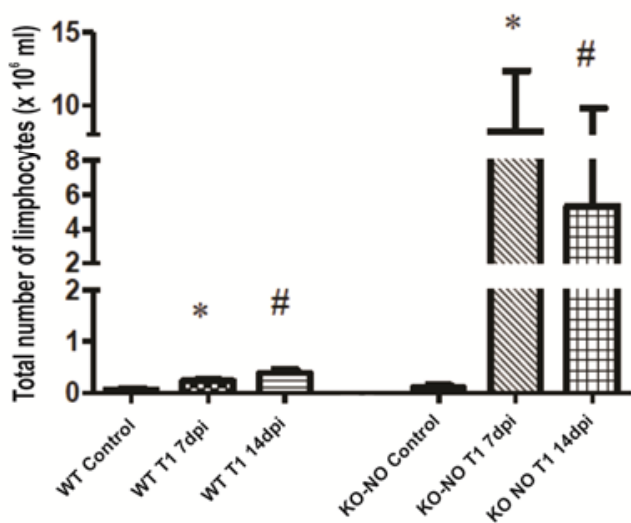

Toledo et al. (2004) showed that animals with a deficiency of iNOS present greater levels of inflammation, probably induced by a tissue parasitism.

B

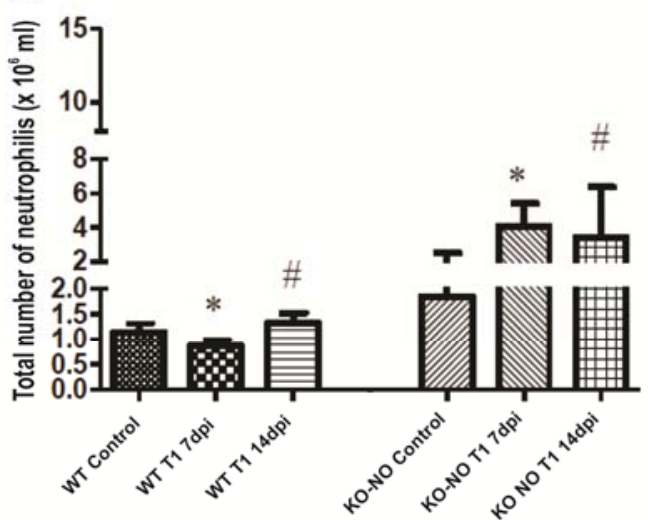

D

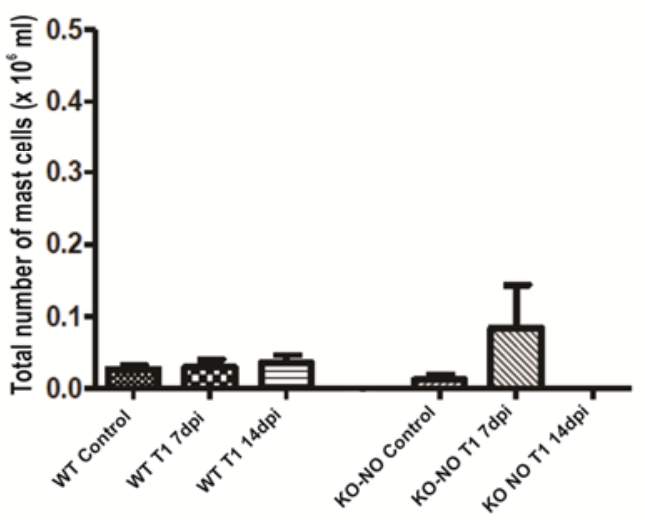

Figure 4. Total number of cells in aspirate from wild-type and KO-NO C57/Black6 mice uninfected (control) and infected with T1 strain at seven and 14dpi. Differential counts using optical microscopy: A) macrophages; B) neutrophils; C) lymphocytes, and D) mastocytes. *statistical significance $(\mathrm{P}<0,05)$.

In addition, herein an increase in the lymphocyte populations was observed in the infected KO-NO C57/Black6 animals. This increase may again be related to the need to compensate for the deficient action of macrophages in KO-NO animals. Probably this increase is related to the subpopulation of B-1 lymphocytes, responsible for the rapid production of $\operatorname{IgM}$ antibodies against microorganisms, present at specific sites, such as in the peritoneum (Hardy et al. 1984).

Previous studies have demonstrated that neutrophils and monocytes are recruited from the blood to infection sites by binding adhesion molecules to endothelial cells and by chemo attractants produced in response to infection (Akira et al., 2006; Pinheiro Junior et al., 2006; Baird and Fontaine, 2007 and Dale et al.,2008). The increased number of macrophage in infected KO mice may indicate that these cells were unable to efficiently eliminate bacterial pathogens due to the deficiency to synthesizing NO. Thus, they necessitate an increased demand for macrophage population. The absence of NO is known to also seemingly potentiate leukocyte migration (Dal Secco et al. 2006). Moreover, increases in the number of neutrophils may also be due to the fact that these cells reach the site of infection first, and, as such, are present at higher 
concentrations at early stages of infection (Bilate, 2007).

Despite the expected finding of mast cells in the peritoneal cavity, no significant increases in this cell population were observed at any of the time points evaluated. This debilitated response due to a lack of NO production may have impeded the migration of these cells; thusly, it is possible that the regulation of immune response may have been encumbered by the decrease in NO concentration (Jamur et al., 2010).

When immunophenotyping was performed on peritoneal cavity cells, mean fluorescence intensity (MIF) measurements for the CD4 marker were found to be significantly higher among both experimental groups $(\mathrm{P}=0.021)$ in comparison to controls at $7 \mathrm{dpi}$, indicating an increase in $\mathrm{CD}^{+} \mathrm{T}$-cells. However, at 14dpi following infection, no significant differences were observed (Figure 5).

With respect to MIF measurements of CD8, no statistically significant differences were observed when comparing either experimental group to its respective controls. However, at $7 \mathrm{dpi}, \mathrm{CD} 8$ readings were significantly higher in the wildtype mice in comparison to $\mathrm{KO}-\mathrm{NO}$ animals $(\mathrm{P}=0.047)$. This difference was not maintained until the 14dpi time point $(\mathrm{P}=0.053)$, despite a sustained elevated tendency (Figure 6).

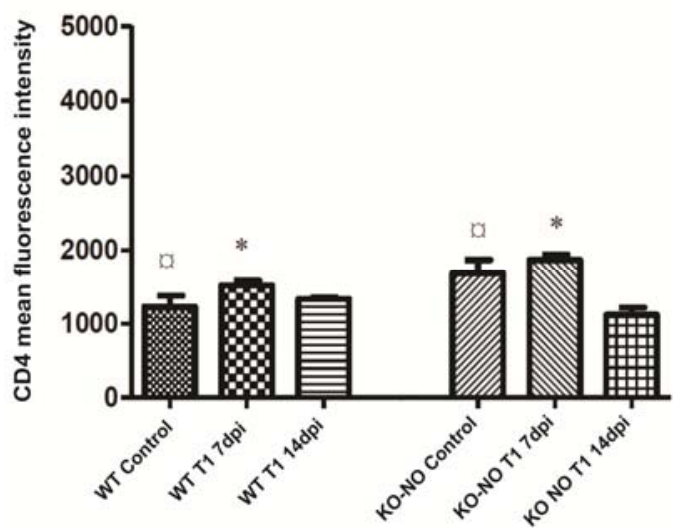

Figure 5. Mean Fluorescence Intensity (MFI) values for CD4 molecules in the spleen homogenate of C57Black/6 wild-type and KO-NO mice infected with CP. Symbols represent values with statistical significance among groups $(\mathrm{P}=0.021, * \mathrm{P}=0.009)$.
The mean fluorescence intensity results presented herein indicate an inversion in the ratio of CD4/CD8 markers, with increases seen in the number of CD8 lymphocytes in relation to CD4 cells. This increase in the population of CD8 Tcells is consistent with what is characteristically seen in infections by this type of facultative intracellular bacteria pathogen, which requires these cells, recruited by the polarization of a Th1 immune response profile, to control the infection. Our results are consistent with a previous study by Valbuena et al. (2002), which found greater numbers of CD8 $\mathrm{T}$ lymphocytes in granulomas at inoculation sites, indicating the influence of this lymphocyte population with respect to its effector and cytotoxic activity to contain the spread of infected macrophages.

The presence of granulomas was investigated in both wild-type and $\mathrm{KO}-\mathrm{NO}$ C57/Black6 mice at $7 \mathrm{dpi}$ and 14dpi following infection with $C$. pseudotuberculosis. None of the wild-type animals presented any evidence of granulomas, yet 5 of $10 \mathrm{KO}-\mathrm{NO}$ mice had granulomas, some even with multiple forms.

The greatest number of granulomas was observed at 7dpi in the inguinal lymph nodes, peritoneal cavity, liver and diaphragm, with values of 4, 2, 1 and 1, respectively. At 14dpi, a single animal presented granulomas in three lymph nodes, two inguinal and one enteric, in addition to a fourth found in its peritoneal cavity.

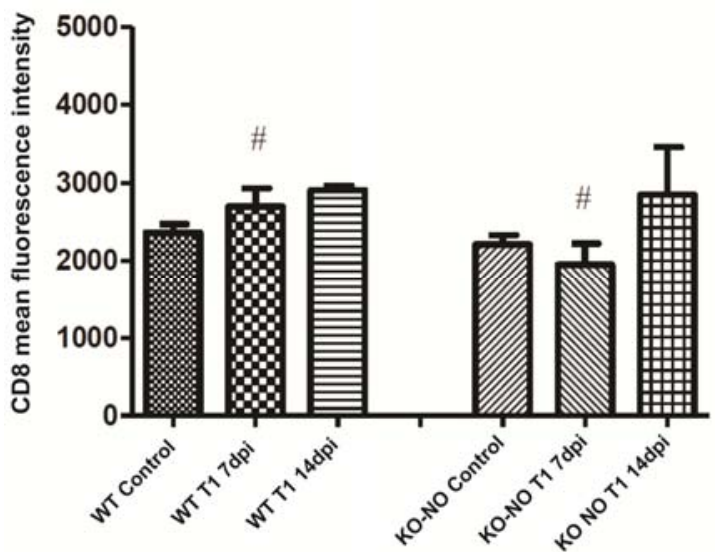

Figure 6. Mean Fluorescence Intensity (MFI) values for $\mathrm{CD} 8$ molecules in the spleen homogenate of C57Black/6 wild-type and KO-NO mice infected with CP. Symbol represent values with statistical significance among groups ( $\# \mathrm{P}=0.009)$. 
Bacterial dissemination was observable in the mesenteric lymph nodes. In the wild-type C57/Black6 mice, just one animal had 40CFU of $\mathrm{CP}$ on the 7dpi. However, two animals in the KO-NO group presented 95 and $185 \mathrm{CFU}$ at $7 \mathrm{dpi}$, while just one animal was found to be infected with 265CFU after 14dpi.

The necropsy findings reported herein corroborate previously reported cellular data. Increases in spleen weight and the presence of disseminated granulomatous lesions observed in KO mice provide evidence that the difficulty involved in eliminating this bacterium consequently facilitated its dissemination.

Furthermore, upon analyzing one of the draining lymph nodes in the peritoneal cavity (i.e. the mesenteric lymph node), it was possible to detect the presence and quantity of this bacterium by quantifying the number of colony forming units, particularly in KO-NO animals. Increases in bacterial CFU in this region are consistent with data reported by Belchior et al. (2006) describing the spread of bacteria from regional lymph nodes to other organs and tissues in accordance with the virulence of the infecting strain and bacterial load. This intensification seen in the KO-NO mice is suggestive of the heightened dissemination of this bacterium due to its ability to escape the immune response, as evidenced by the number of granulomas found in these animals. The elevated spread may once again be related to the absence of $\mathrm{NO}$, since macrophages arriving at the lymph nodes harbor viable bacteria and, as such, may further facilitate the spread of this pathogen (Ozbek et al., 2009).

In an attempt to evaluate humoral immune response, an indirect ELISA was used to quantify total IgG and this antibody's subclasses (IgG1, $\operatorname{IgG} 2 \mathrm{a}, \operatorname{IgG} 2 \mathrm{~b}$ and $\operatorname{IgG} 3$ ) in the wild-type and KO-NO mice euthanized at 14dpi. No statistically significant differences were detected among the comparison groups. This relatively short timeframe was insufficient for the development of a detectable humoral immune response against $\mathrm{CP}$. According to Paule et al. (2003), goats infected by CP presented a primary response of short duration on the fifth day postinfection, with this presentation evolving into a more pronounced and long-lasting secondary response only on day 16. Moreover, Tatibana et al. (2007) were able to observe a humoral response only at $14 \mathrm{dpi}$ in an experiment involving dd $\mathrm{Y}$ mice.

Considering the findings herein, the authors feel that compelling evidence has been presented regarding the fundamental importance of NO synthesis in the inflammatory response induced to eliminate $\mathrm{CP}$.

\section{CONCLUSION}

The results strongly suggest the importance of $\mathrm{NO}$ in the process of controlling $\mathrm{CP}$ infection, as NO-KO animals were observed to be markedly more affected by infection with this bacterium.

\section{REFERENCES}

AKIRA, S.; UEMATSU, S.; TAKEUCHI, O. Pathogen recognition and innate immunity. Cell, v.124, p.783-801, 2006.

BAIRD, G.J.; FONTAINE, M.C. Corynebacterium pseudotuberculosis and its role in ovine caseous lymphadenitis. J. Comp. Pathol., v.137, p.179-210, 2007.

BASTOS, B.L.; PORTELA, R.W.D.; DORELLA, F.A. et al. Corynebacterium pseudotuberculosis: immunological responses in animal models and zoonotic potential. J. Clin. Cell Immunol., 2012.

BELCHIOR, S.E.; GALLARDO, A.; ABALOS, A. et al. Actualizacion sobre linfoadenitis caseosa: el agente etiológico y laenfermedad. Rev. Vet. Argent., v.23, p.258-278, 2006.

BILATE, A.M.B. Inflamação, citocinas, proteínas de fase aguda e implicações terapêuticas. Temas Reumatol. Clin., v.8, p.4745, 2007.

BORGES, C.R.B.; RODRIGUES JUNIOR, V.; REIS, M.A.D. et al. Role of nitric oxide in the development of cardiac lesions during the acute phase of experimental infection by Trypanosomacruzi. Rev. Soc. Bras. Med. Trop., v.42, p.170-174, 2009.

CARMINATI, R.; BAHIA, R.; MOURA COSTA, L.F. et al. Determinação da sensibilidade e da especificidade de um teste de ELISA indireto para o diagnóstico de linfadenite caseosa em caprinos. Rev. Cienc. Med. Biol., v.2, p.88-93, 2003. 
CHARO, I.F.; RANSOHOFF, R.M. The many roles of chemokines and chemokine receptors in inflammation. N. Engl. J. Med., v.354, p.610621, 2006

DALE, D.C.; BOXER, L.; LILES W.C. The phagocytes: neutrophils and monocytes. Blood J., v.112, p.935-945, 2008.

DAL-SECCO, D.; MOREIRA, A.P.; FREITAS, A. et al. Nitric oxide inhibits neutrophil migration by a mechanism dependent on ICAM-I sole of soluble guanylate cyclase. Nitric Oxide, v.15, p77-86, 2006.

DIAS, A.S.S.O.; SILVA JR., F.C.; SANTOS, L.S. et al. Strain-dependent arthritogenic potential of the zoonotic pathogen Corynebacterium ucerans. Vet. Microbiol., v.153, p.323-331, 2011.

DUSSE, L.M.S.; VIEIRA, L.M.; CARVALHO, M.G. Revisão sobre óxido nítrico. J. Bras. Patol. Med. Lab., v.39, p.343-350, 2003.

GUIMARÃES, A.S.; SEYFFERT, N.; BASTOS, B.L. et al. Caseous lymphadenitis in sheep flocks of the state of Minas Gerais, Brazil: prevalence and management surveys. Small Ruminant Res., v.87, p.86-91, 2009.

HARDY, R.R.; HAYAKAWA, K.; PARKS, D.R.; HERZENBERG, L.A. Murine B cell differentiation lineages. J. Exp. Med., v.159, p.1169-1188, 1984.

JAMUR, M.C.; MORENO, A.N.; MELLO, L.F. et al. Mast cell repopulation of the peritoneal cavity: contribution of mast cell progenitors versus bone marrow derived committed mast cell precursors. BMC Immunol., v.11, p.32, 2010.

MOTTA, R.G.; CREMASCO, A.D.C.M.; RIBEIRO, M.G. Infecções por Corynebacterium pseudotuberculosis em animais de produção. Vet. Zootec., v.17, p.200-213, 2010.

OLIVEIRA, L.I.D.; PRADO, J.D.S.; CUNHA, B.M.D. et al. Criptococose pulmonar associada à infecção sistêmica por Corynebacterium pseudotuberculosis em cabra (Capra hircus). Ciênc. Rural, v.41, p.1262-1265, 2011.

OZBEK, E.; ILBEY, Y.O.; CEKMEN, M. et al. Bacterial translocation to kidney in rats with intestinal obstruction and the role of nitric oxide. Arch. Ital. Urol. Androl., v.81, p.56-58, 2009.
PAULE, B.J.A.; AZEVEDO, V.; REGIS, L.F. et al. Experimental Corynebacterium pseudotuberculosis primary infection in goats: kinetics of $\mathrm{IgG}$ and interferon- $\gamma$ production, $\operatorname{IgG}$ avidity and antigen recognition by Western blotting. Vet. Immunol. Immunopathol., v.96, p.129-139, 2003.

PINHEIRO JUNIOR, J.W.; OLIVEIRA, A.A.F.; ALVES, F.S.F. et al. Corynebacterium pseudotuberculosis experimental infection of goats mamary gland. Arq. Inst. Biol., v.73, p.395-400, 2006.

RAMOS, R.T.J.; SILVA, A.; CARNEIRO, A.R. et al. Genome sequence of the corynebacterium pseudotuberculosis Cp316 strain, isolated from the abscess of a Californian horse. J. Bacteriol., v.194, p.6620-6621, 2012.

SILVA, W.M.; CARVALHO, R.D.; SOARES S.C. et al. Label-free proteomic analysis to confirm the predicted proteome of Corynebacterium pseudotuberculosis under nitrosative stress mediated by nitric oxide. BMC Genomics, v.15, p.1065, 2014.

TATIBANA, B.T.; SANO, A.; UNO, J. et al. Resposta imune humoral na paracoccidioidomicose experimental em camundongos ddY. Semin. Ciênc. Agrár., v.28, p.287-294, 2007.

TOLEDO, M.J.O.; BAHIA, M.T.; VELOSO, V.M. et al. Effects of specific treatment on parasitological and histopathological parameters in mice infected with different Trypanosomacruzi clonal genotypes. $J$. Antimicrob. Chemother., v.53, p.1045-1053, 2004.

TROST, E.; OTT, L.; SCHNEIDER, J. et al. The complete genome sequence of Corynebacterium pseudotuberculosis FRC41 isolated from a 12year-old girl with necrotizing lymphadenitis reveals insights into gene-regulatory networks contributing to virulence. BMC Genomics, v.11, p.728, 2010.

VALBUENA， G.; FENG， H.M.; WALKER, D.H. Mechanisms of immunity against rickettsiae. New perspectives and opportunities offered by unusual intracellular parasites. Microbes Infec., v.4, p.625-633, 2002. 